\title{
Rancang Bangun Sistem Informasi Konsultasi Hukum Berbasis Android
}

\author{
A Design and Development of Android Based Legal Consultation Information System
}

\author{
Antonius Wahyu Sudrajat ${ }^{1}$, Inayatullah ${ }^{2}$ \\ ${ }^{1,2}$ Program Studi Manajemen Informatika, AMIK MDP, Palembang \\ E-mail: ${ }^{1}$ wahyu.sudrajat@mdp.ac.id, ${ }^{2}$ inayatullah@mdp.ac.id
}

\begin{abstract}
Abstrak
Informasi sangat dibutuhkan oleh setiap orang, termasuk informasi mengenai hukum. Untuk mendapatkan informasi hukum yang benar, harus bersumber dari orang yang paham atau mengerti mengenai masalah hukum tersebut. Pelaksanaan konsultasi hukum diperlukan untuk mendapatkan informasi dan langkah-langkah hukum secara lebih tepat dan cepat. Tujuan dari penelitian ini adalah untuk mengembangkan sebuah sistem informasi konsultasi hukum berbasis android yang dapat digunakan oleh masyarakat dalam mendapatkan informasi dan konsultasi hukum. Metode pengembangan sistem yang digunakan memiliki tahapan, yaitu: pengumpulan data, identifikasi masalah, analisis masalah, perancangan sistem, implementasi dan dokumentasi. Unified Modelling Language (UML) merupakan metode pemodelan yang dipilih untuk perancangan sistem berorientasi objek dalam pengembangan sistem ini. Dimana diagramdiagram yang digunakan diantaranya adalah use case diagram, activity diagram, sequence diagram dan class diagram. Dengan dibangunnya sistem informasi konsultasi hukum berbasis android dapat mempercepat masyarakat dalam mendapatkan informasi dan pendampingan hukum. Selain itu, memberikan kemudahan bagi pejabat hukum dalam evaluasi dan monitoring perkara yang dihadapi oleh klien.
\end{abstract}

Kata kunci: Sistem Informasi, Konsultasi, Hukum, Android

\begin{abstract}
Information is needed by everyone, including information about the law. To get correct legal information, it must come from a person who understands or understands the legal issue. The implementation of legal consultation is needed to obtain information and legal steps more precisely and quickly. The purpose of this research is to develop an android-based legal consultation information system that can be used by the public in obtaining legal information and consultation. The system development method used has stages, namely: data collection, problem identification, problem analysis, system design, implementation and documentation. Unified Modeling Language (UML) is the modeling method chosen for object-oriented system design in the development of this system. Where the diagrams used include use case diagrams, activity diagrams, sequence diagrams and class diagrams. With the construction of an Androidbased legal consultation information system, it can accelerate the community in obtaining information and legal assistance. In addition, it makes it easy for legal officials to evaluate and monitor cases faced by clients.
\end{abstract}

Keywords: Information System, Consultation, Law, Android

\section{PENDAHULUAN}

Informasi dibutuhkan oleh setiap orang, salah satu informasi yang dibutuhkan berhubungan dengan informasi mengenai hukum. Tidak semua orang paham mengenai aturanaturan yang berlaku dalam hukum. Untuk mengatasi permasalahan dalam hukum dibutuhkan 
orang atau pejabat yang paham akan hukum. Orang atau pejabat yang paham akan hukum tersebut dapat memberikan pelayanan atau konsultasi hukum terhadap masyarakat. Masyarakat yang membutuhkan jasa hukum tersebut dapat dapat datang langsung ke tempat mereka atau menghubungi melalui telpon untuk konsultasi.

Dalam melayani masyarakat ini, pejabat hukum merasa kurang efektif dan efisien karena masyarakat tidak mendapatkan pendampingan secara cepat terhadap permasalahan hukum yang sedang dialami. Pejabat hukum sebagai konsultan hukum memiliki keterbatasan waktu dalam memberikan pendampingan hukum

Berdasarkan uraian di atas pejabat hukum ingin mengatasi permasalahan pelayanan konsultasi hukum tersebut dengan pemanfaatan teknologi informasi. Pemanfaatan teknologi informasi sudah merambah semua bidang pekerjaan termasuk bidang hukum. Dengan adanya pemanfaatan teknologi informasi, permasalahan waktu dan biaya dalam konsultasi hukum dapat dikurangi. Untuk itu, peneliti merasa perlu melakukan penelitian dengan judul Rancang Bangun Sistem Informasi Konsultasi Hukum Berbasis Android.

Ruang lingkup penelitian bertujuan untuk mengarahkan kegiatan pengembangan sistem agar tidak menyimpang, hal tersebut dikarenakan permasalahan yang ada sifatnya kompleks. Ruang lingkup penelitian hanya sebatas konsultasi hukum tidak sampai menghitung biaya. Menggunakan perangkat lunak android. Tool yang digunakan UML (Unified Modelling System).

Tujuan dalam penelitian untuk mengurangi permasalahan waktu dan biaya dalam pelayanan konsultasi terhadap masyarakat. Manfaat dari penelitian, masyarakat menjadi cepat dalam mendapatkan informasi yang dibutuhkan. Biaya yang dikeluar bisa lebih hemat.

\section{METODE PENELITIAN}

\subsection{Metodologi Penelitian}

Metodologi penelitian menjelaskan tahapan-tahapan yang dilakukan dalam pengembangan sistem. Pada penelitian ini tahapan-tahapan yang dilakukan ditunjukkan pada gambar 1.

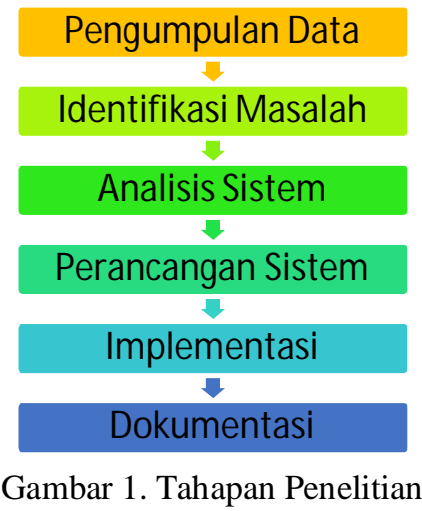

\section{Pengumpulan Data}

Tahapan ini merupakan tahapan awal dalam pengembangan sistem yang dilakukan. Beberapa teknik pengumpulan data dilakukan yaitu Pertama Studi literatur, yaitu membaca jurnal, buku dan beberapa perundang-undangan terkait dengan pengembangan sistem konsultasi hukum dan aturan-aturan yang berlaku. Kedua wawancara, yaitu dengan cara bertanya langsung dengan beberapa konsultan hukum yang ada di kota Palembang terkait dengan proses atau prosedur dalam konsultasi hukum serta permasalahannya. Ketiga 
observasi, yaitu dengan mengamati secara langsung bagaimana proses konsultasi yang dilakukan oleh masyarakat dengan konsultan hukum.

\section{Identifikasi Masalah}

Berdasarkan hasil pengumpulan data pada tahapan sebelumnya, maka langkah selanjutnya adalah melakukan identifikasi permasalahan yang dihadapi baik dari sisi konsultan maupun dari sisi masyarakat yang membutuhkan layanan konsultasi hukum. Dalam penentuan permasalahan pengguna tetap dilibatkan sehingga didapatkan permasalahan yang tepat.

\section{Analisis Sistem}

Berdasarkan permasalahan yang telah ditetapkan dan diverifikasi oleh setiap calon pengguna, langkah selanjutnya adalah melakukan analisis masalah secara lebih mendalam. Untuk melakukan analisis masalah akan digunakan tabel matriks sebab akibat. Dari analisis masalah didapatkan kebutuhan sistem, yang selanjutnya akan di lihat berdasarkan fungsionalnya dan non fungsional. Alat bantu dalam mendefinisikan kebutuhan fungsional akan digunakan diagram use case.

\section{Perancangan Sistem}

Tahapan ini adalah tahapan merancang sistem konsultasi hukum berdasarkan kebutuhan fungsional yang telah didefinisikan pada tahapan sebelumnya secara rinci. Dalam melakukan perancangan akan digunakan pemodelan berorientasi objek yaitu dengan diagram-diagram pada UML. Diagram yang digunakan diantaranya adalah Diagram activity, diagram class dan diagram sequence. Untuk melengkapi gambaran sistem secara utuh dalam penelitian ini juga akan digambarkan arsitektur dari sistem jaringan yang digunakan dalam implementasi sistem.

\section{Implementasi}

Rancangan sistem informasi yang telah dibuat selanjutnya diterjemahkan kedalam bahasa pemrograman sehingga dapat digunakan. Bahasa pemrograman yang akan digunakan dalam pengembangan sistem konsultasi hukum adalah bahasa pemrograman java untuk android. Sedangkan database angine yang digunakan adalah MySQL.

\section{Dokumentasi}

Tahapan ini merupakan tahapan penyusunan atau dokumentasi dari hasil penelitian ini.

\subsection{Sistem}

Menurut Andri Kristanto sistem adalah suatu jaringan kerja dari prosedur-prosedur yang saling berhubungan, berkumpul bersama-sama untuk melakukan suatu kegiatan atau menyelesaikan suatu sasaran tertentu [1]. Sedangkan menurut Hanif Al Fatta Sistem dapat diartikan sebagai suatu kumpulan dari unsur atau variabel-variabel yang saling terorganisir, saling berinteraksi, dan saling bergantung sama lain [2].

\subsection{Informasi}

Menurut Tata Sutabri dalam bukunya yang berjudul Analisis Sistem Informasi, Informasi adalah makna yang dapat ditafsirkan dari pesan atau kumpulan pesan [3]. Sedangkan menurut Wahyuni Reksoatmodjo informasi adalah data yang telah diolah sehingga pengetahuan dari orang yang menggunakan data mengalami peningkatan [4].

\subsection{Sistem Informasi}

Menurut Tata Sutabri dalam bukunya yang berjudul Analisis Sistem Informasi, adalah kombinasi dari teknologi informasi dan aktivitas orang yang menggunakan teknologi itu untuk mendukung operasi dan manajemen[5]. Sedangkan menurut Abdul Kadir sistem informasi 
mencakup sejumlah komponen (manusia, teknologi informasi, komputer, dan prosedur kerja), ada sesuatu yang diproses (data menjadi informasi), dan dimaksudkan untuk mencapai suatu sasaran atau tujuan [6 ].

\subsection{Layanan Konsultasi Hukum}

Orang yang memberikan konsultasi hukum sesuai persyaratan undang-undang yang berlaku disebut sebagai advokat. Jasa hukum merupakan jasa yang diberikan oleh advokat berupa pemberian konsultasi hukum, bantuan hukum, menjalankan kuasa, mewakili, mendampingi, membela dan melakukan tindakan hukum lain untuk kepentingan klien [7].

\subsection{Android}

Android merupakan sebuah sistem operasi perangkat mobile berbasiskan linux yang mencakup sistem operasi, middleware, dan aplikasi. Pada tanggal 5 November 2007, android dirilis pertama kali [8].

\subsection{Unified Modeling Language}

Satu kumpulan konversi pemodelan yang digunakan untuk menentukan atau menggambarkan sebuah sistem software yang terkait dengan objek [9].

\subsection{Penelitian Sebelumnya}

Beberapa penelitian telah dilakukan terhadap sistem konsultasi hukum, penelitian sebelumnya dapat dilihat pada tabe11.

Tabel 1. Penelitian Sebelumnya

\begin{tabular}{|c|c|c|}
\hline No & Judul & Ulasan \\
\hline 1. & $\begin{array}{l}\text { Sistem Informasi Konsultasi Berbasis Web } \\
\text { Studi Kasus: PT. Taspen (Persero) Cabang } \\
\text { Bandung [10] }\end{array}$ & 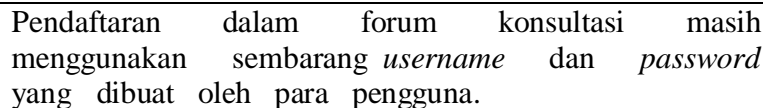 \\
\hline 2. & $\begin{array}{l}\text { Rancang Bangun Sistem Informasi Data } \\
\text { Konsultasi Perkara Klien Pada Biro } \\
\text { Konsultasi Dan Bantuan Hukum (BKBH) } \\
\text { Universitas Stikubank (UNISBANK) } \\
\text { Semarang [11] }\end{array}$ & $\begin{array}{l}\text { Tujuan dari penelitian ini adalah mempermudah proses } \\
\text { penyimpanaan, pengeditan dan pencarian data konsultasi } \\
\text { dan mempermudah pelacakan kemajuan perkara. Penelitian } \\
\text { ini lebih kepada administrasi dan kearsipan dokumen } \\
\text { konsultasi. }\end{array}$ \\
\hline 3 & $\begin{array}{l}\text { Pengembangan Sistem Informasi Lembaga } \\
\text { Pengkajian dan Konsultan Bantuan Hukum } \\
\text { (LPKBH) Menggunakan } \text { Zachman } \\
\text { Framework (Studi Pada LPKBH Al- } \\
\text { Baihaqy) [12] }\end{array}$ & $\begin{array}{l}\text { Penelitian ini melakukan analisis terhadap proses bisnis } \\
\text { yang berjalan kemudian membuat usulan proses bisnis } \\
\text { yang baru. Untuk membuat usulan proses bisnis yang baru } \\
\text { digunakkan zachman framework yang melihat dari } \\
\text { perspektif planner, perspektif owner, perspektif designer } \\
\text { dan perspektif builder. }\end{array}$ \\
\hline
\end{tabular}

Pada penelitian yang dilakukan oleh penulis, hanya untuk pendataan awal proses konsultasi awal oleh masyarakat kepada pejabat hukum dan memperrmudah komunikasi dimana hasil komunikasi dapat tersimpan dengan baik sehingga dapat dipelajari kembali oleh masingmasing pihak untuk dievaluasi.

\section{HASIL DAN PEMBAHASAN}

\subsection{Analisis Sistem}

Pada tahapan ini terdiri dari beberapa langkah diantaranya adalah identifikasi masalah, analisis masalah dan analisis kebutuhan sistem.

\subsubsection{Identifikasi Masalah}

Beberapa permasalahan yang di temukan dan telah diverifikasi adalah sebagai berikut: 
1. Masyarakat tidak mendapatkan pendampingan secara tepat terhadap permasalahan hukum yang sedang dialami.

2. Pejabat hukum sebagai konsultan hukum memiliki keterbatasan waktu dalam memberikan pendampingan hukum.

\subsubsection{Analisis Masalah}

Permasalahan yang telah di definisikan sebelumnya, selanjutnya dilakukan analisis secara mendalam. Untuk melakukan analisis masalah digunakan matriks sebab akibat, seperti ditunjukkan pada tabel 2.

Tabel 2. Matriks Sebab Akibat

\begin{tabular}{|c|c|c|c|}
\hline \multicolumn{2}{|c|}{ Analisis Sebab dan Akibat } & \multicolumn{2}{|c|}{ Tujuan-tujuan perbaikan Sistem } \\
\hline Masalah & Sebab Akibat & Tujuan Sistem & Batasan Sistem \\
\hline $\begin{array}{l}\text { Masyarakat tidak } \\
\text { mendapatkan } \\
\text { pendampingan } \\
\text { secara tepat } \\
\text { terhadap papan } \\
\text { permasalahan } \\
\text { hukum yang } \\
\text { sedang dialami }\end{array}$ & $\begin{array}{l}\text { Sebab: } \\
\text { Masyarakat tidak memiliki akses } \\
\text { yang cepat untuk mendapatkan } \\
\text { informasi atau pendampingan } \\
\text { terhadap permasalahannya } \\
\text { Akibat: } \\
\text { Keterlambatan penangan } \\
\text { masalah menyebabkan masalah } \\
\text { sulit untuk diatasi }\end{array}$ & $\begin{array}{l}\text { Membangun sebuah } \\
\text { sistem yang dapat } \\
\text { diakses oleh masyarakat } \\
\text { secara cepat dan mudah } \\
\text { tanpa terbatas waktu dan } \\
\text { tempat }\end{array}$ & $\begin{array}{l}\text { 1. Sistem memiliki } \\
\text { interface yang } \\
\text { mudah digunakan } \\
\text { oleh masyarakat } \\
\text { 2. Sistem memberikan } \\
\text { respon yang cepat }\end{array}$ \\
\hline $\begin{array}{l}\text { Advokat sebagai } \\
\text { konsultan hukum } \\
\text { memiliki } \\
\text { keterbatasan } \\
\text { waktu dalam } \\
\text { memberikan } \\
\text { pendampigan } \\
\text { hukum }\end{array}$ & $\begin{array}{l}\text { Sebab: } \\
\text { Peningkatan akan permasalahaan } \\
\text { hukum saat ini membuat } \\
\text { konsultan hukum memiliki } \\
\text { jumlah klien yang banyak } \\
\text { Akibat: } \\
\text { Pelayanan konsultasi oleh } \\
\text { hukum menjadi sulit dilakukan }\end{array}$ & 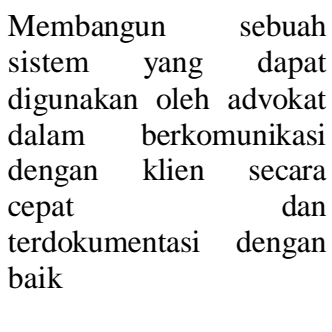 & $\begin{array}{l}\text { 1. Sistem harus } \\
\text { interaktif sehingga } \\
\text { memudahkan } \\
\text { advokat dalam } \\
\text { berkomunikasi } \\
\text { dengan klien }\end{array}$ \\
\hline
\end{tabular}

\subsubsection{Analisis Kebutuhan}

a. Kebutuhan Fungsional

Diagram use case digunakan sebagai model untuk menggambarkan kebutuhan fungsional sistem konsultasi hukum berbasis android, yang ditunjukan pada gambar 2 . 


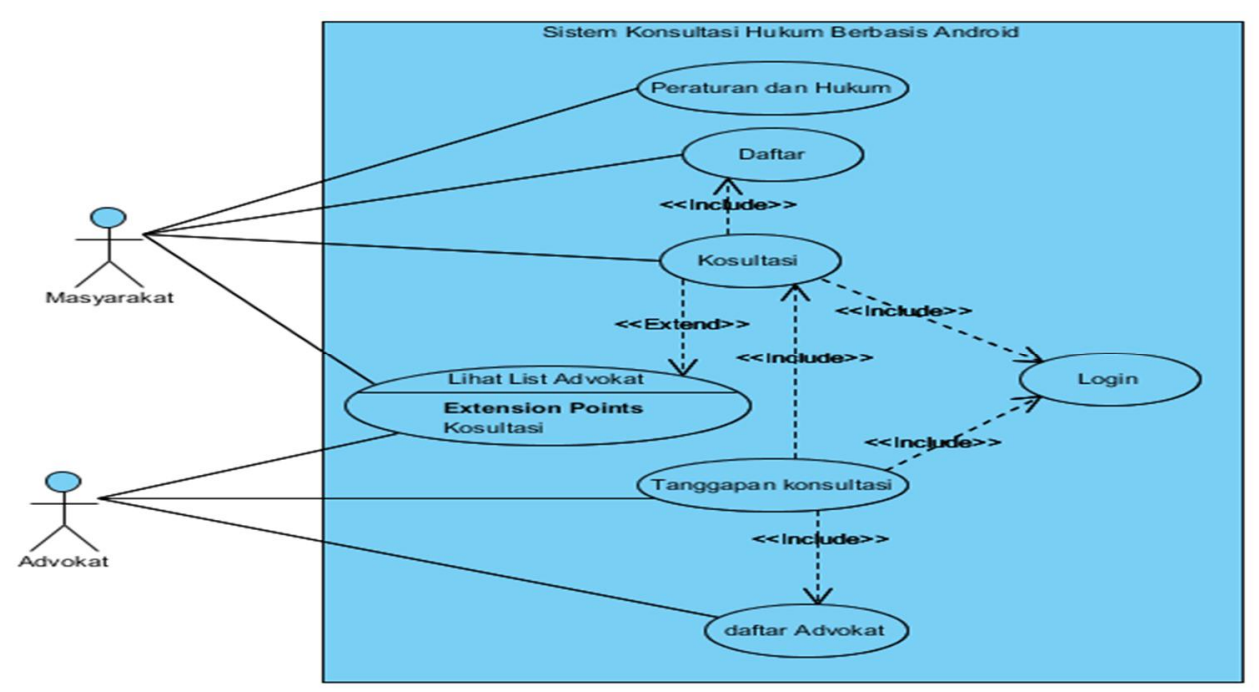

Gambar 2. Diagram Use Case

b. Kebutuhan Non Fungsional

Kebutuhan non fungsional merupakaan kebutuhaan yang harus dimiliki untuk mendukung kebutuhan fungsional yaitu:

1) Reliability, sistem konsultasi hukum berbasis android harus mudah diakses oleh masyarakat dan advokat.

2) Performance, yaitu: kinerja dari aplikasi harus dapat diandalkan sehingga dapat digunakan dengan cepat.

3) Userfriendly, Sistem memiliki tampilan yang mudah dipahami.

4) Security requirements, Memiliki otorisasi pengguna, seperti login.

\subsection{Rancangan Sistem}

\subsubsection{Rancangan Prosedural}

a. Activity Diagram Login

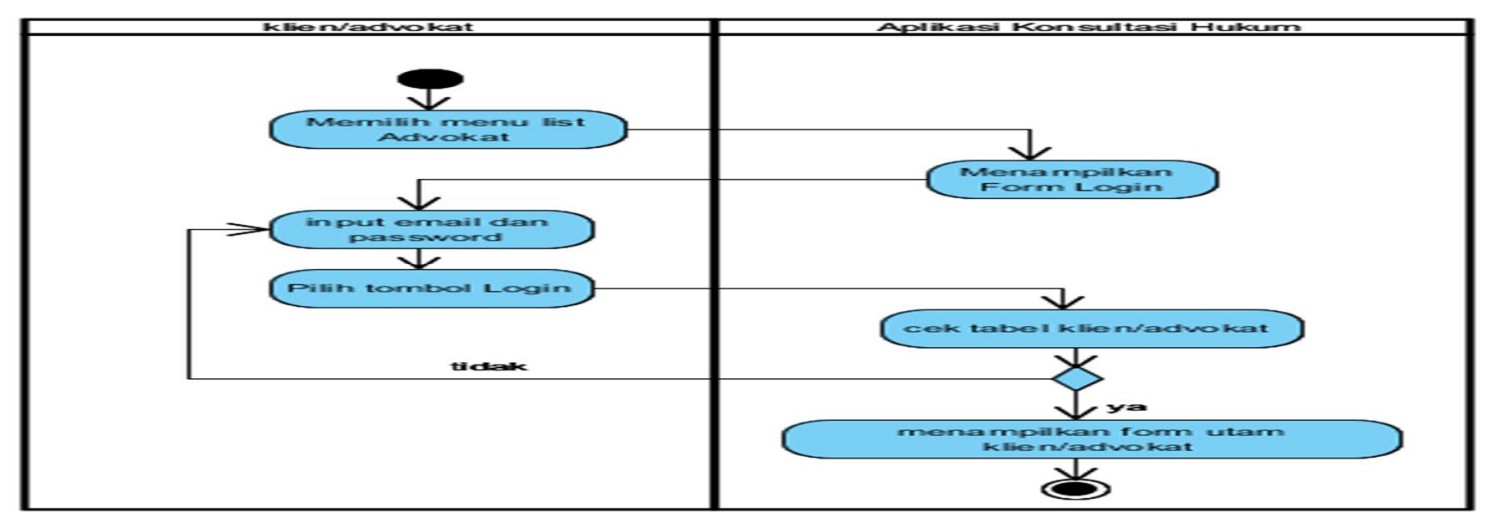

Gambar 3. Rancangan Activity Diagram Login 
b. Activity Diagram Konsultasi

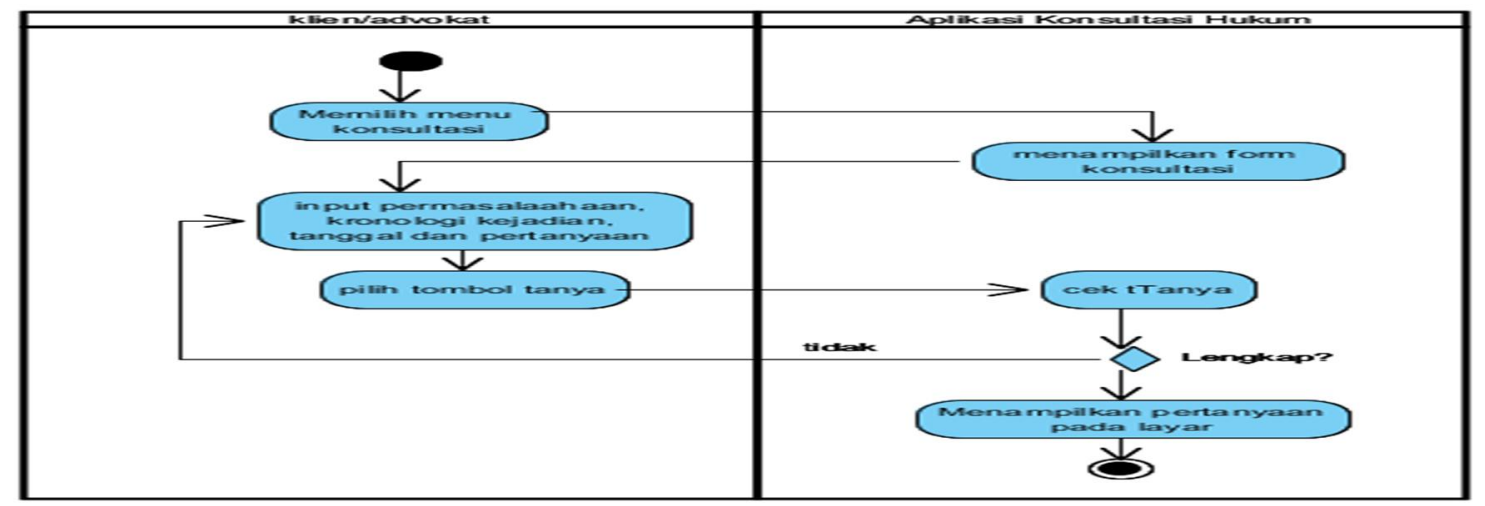

Gambar 4. Rancangan Activity Diagram Konsultasi

c. Activity Diagram List Advokat

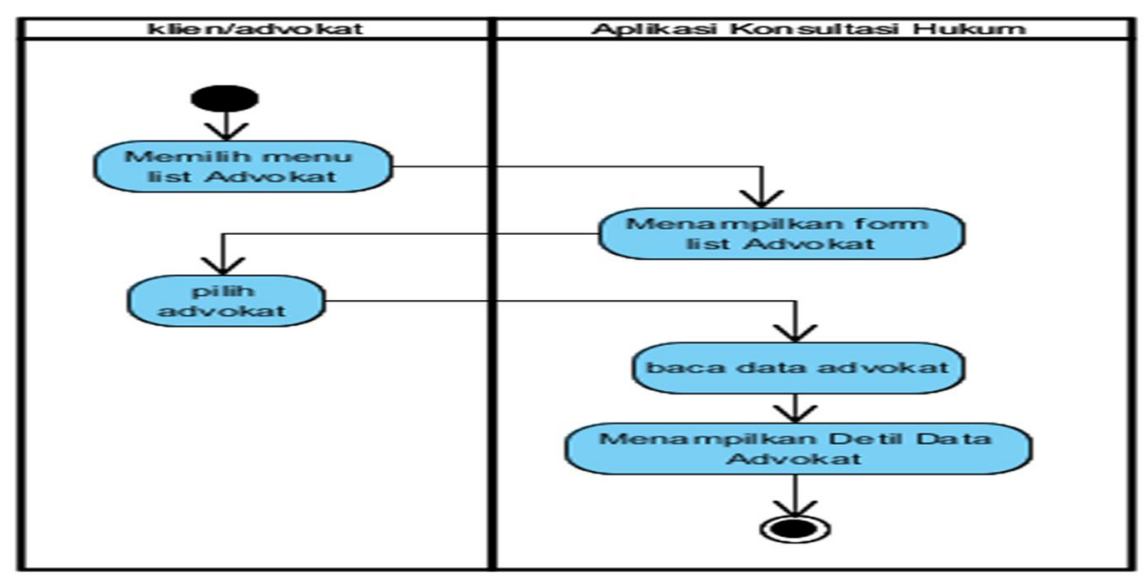

Gambar 5. Rancangan Activity Diagram List Advokat

\subsubsection{Rancangan Hubungan Antar Objek}

a. Sequence Diagram Login

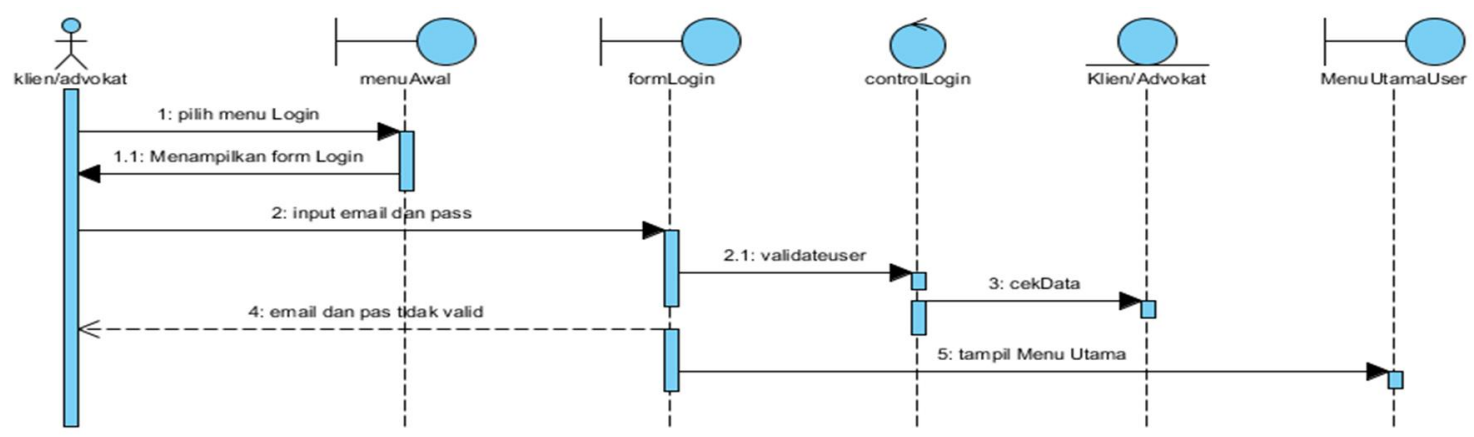

Gambar 6. Rancangan Sequence Diagram Login 
b. Sequence Diagram Konsultasi

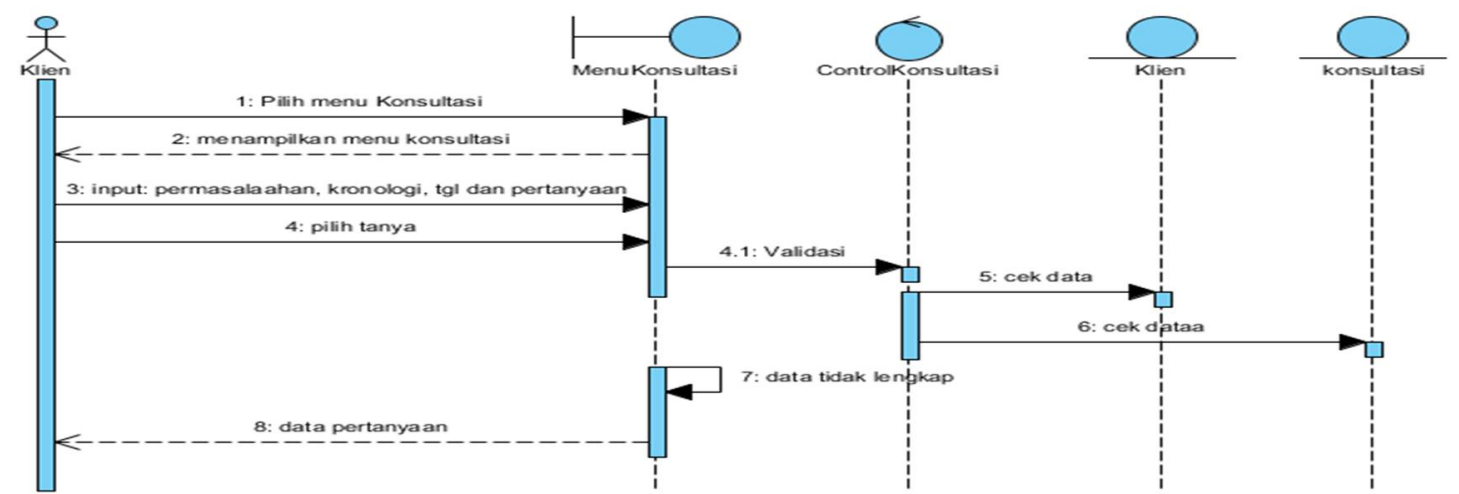

Gambar 7. Rancangan Sequence Diagram Konsultasi

c. Sequence Diagram List Advokat

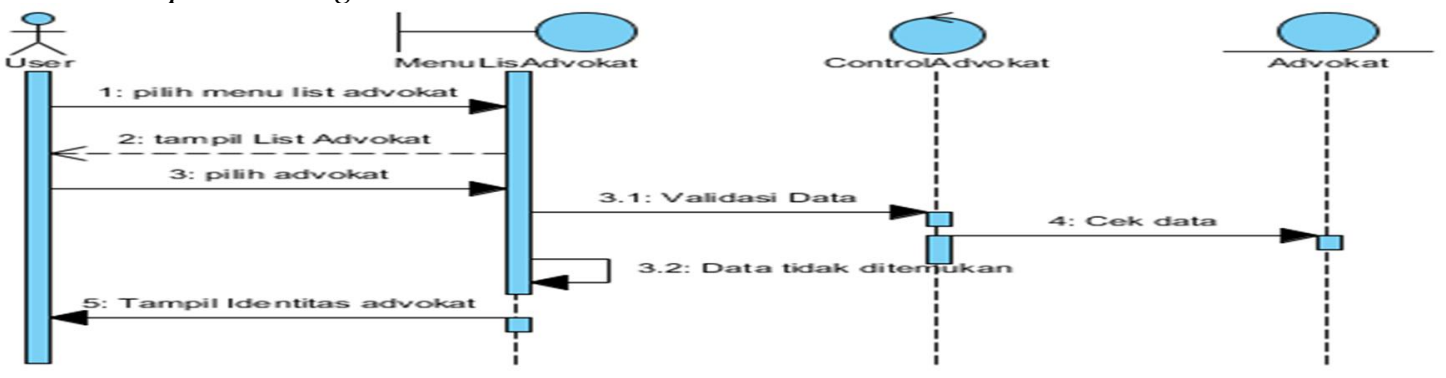

Gambar 8. Rancangan Sequence Diagram List Advokat

\subsubsection{Rancangan Class}

Rancangan Class merupakaan jenis-jenis obyek dalam sistem yang terjadi. Rancangan class konsultasi hukum dapat dilihat pada gambar 9.

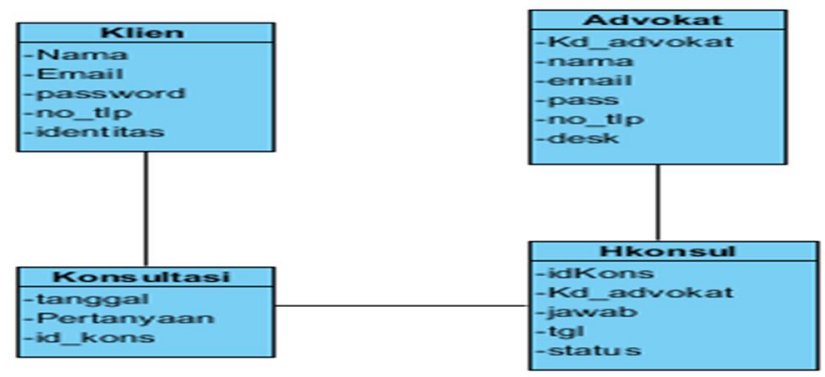

Gambar 9. Rancangan Class Diagram

\subsection{Implementasi}

a. Halaman Utama

Halaman ini merupakan halaman awal dari aplikasi konsutasi hukum. Terdapat empat menu utama yaitu: peraturan dan hukum, List Advokat, Daftar dan Login. Halaman utama pada aplikasi ini ditunjukkan pada gambar 10 . 


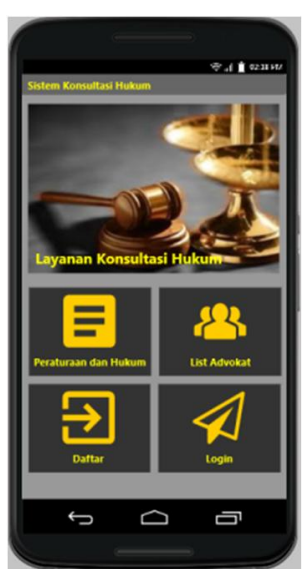

Gambar 10. Halaman Utama

\section{b. Halaman Peraturan dan Hukum}

Halaman ini memuat peraturan-peraturan hukum yang dapat dibaca oleh pengguna sebagai referensi atau pemahaman terkait dengan hukum yang berlaku. Peraturan ini berupa file pdf yang setelah mengguna memilih peraturan yang ingin di baca. Halaman peraturan dan hukum ditunjukkan pada gambar 11.

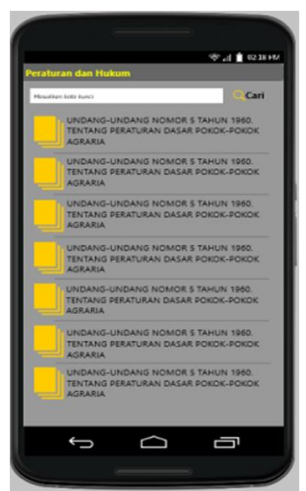

Gambar 11. Halaman Peraturan dan Hukum

\section{c. Halaman Login}

Halaman ini digunakan oleh pengguna aplikasi, baik masyarakat maupun advokat yang tentunnya sudah melalui proses daftar sebagai pengguna aplikasi konsultasi hukum. Halaman login ditunjukkan pada gambar 12.

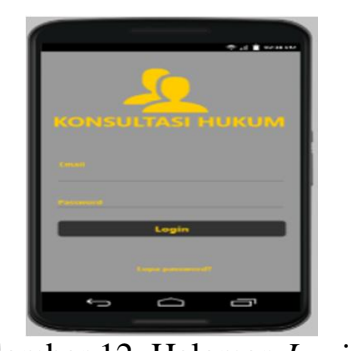

Gambar 12. Halaman Login

\section{d. Halaman Daftar}

Halaman ini digunakan oleh masyarakat sebelum melakukan konsultasi hukum. Dalam pendaftaran masyarakat harus menyertakan identitas pengenal diri seperti kartu tanda penduduk (KTP) atau yang lainnya. Halaman daftar ditunjukkan pada gambar 13. 


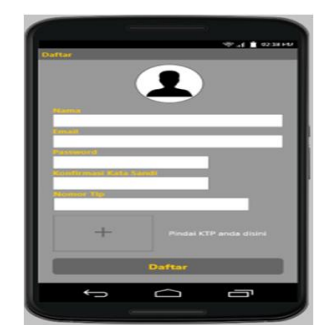

Gambar 13. Halaman Daftar

\section{e. Halaman Konsultasi}

Halaman ini diakses oleh masyarakat setelah mendaftar sebagai klien. Pada form ini klien dapat menanyakan permasalahan hukum yang sedang dialaminya kepada konsultan. Halaman konsultasi ditunjukkan pada gambar 14.

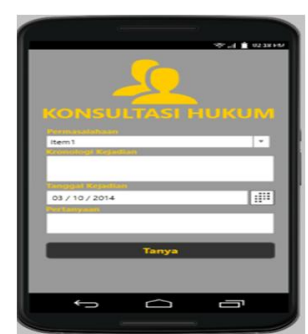

Gambar 14. Halamaan Konsultasi

\subsection{Arsitektur Jaringan}

Gambar 15 merupakan rancangan arsitektur aplikasi konsultasi hukum berbasis android. Ada dua server dalam rancangan arsitektur ini, yaitu: server aplikasi dan server database. Sebelum aplikasi diakses oleh pengguna harus melalui firewall terlebih dahulu.

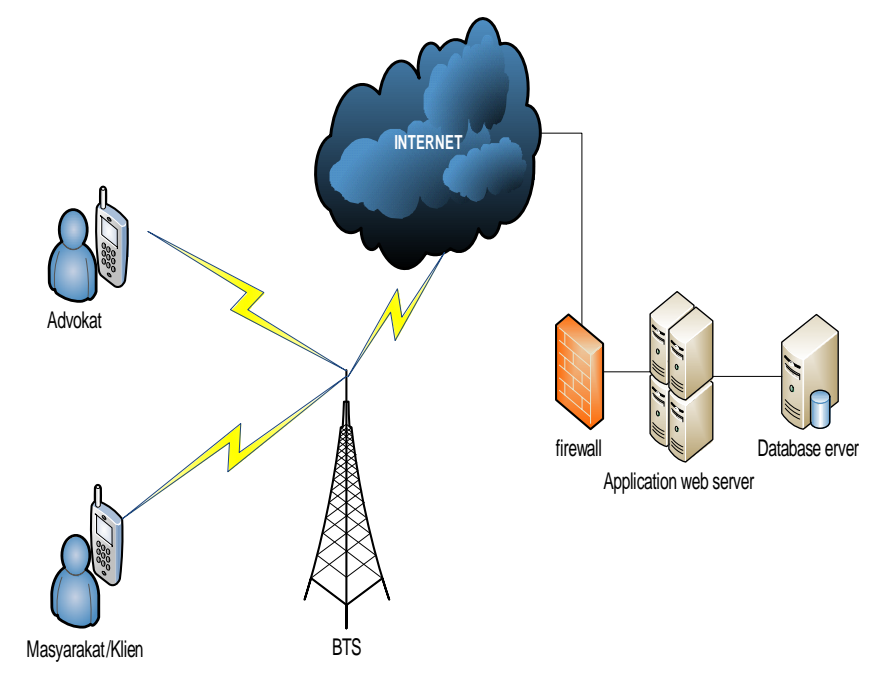

Gambar 15. Rancangan Arsitektur Aplikasi

\section{KESIMPULAN DAN SARAN}

\subsection{Kesimpulan}

Berdasarkan hasil implementasi dapat ditarik beberapa kesimpulan yaitu:

1. Aplikasi konsultasi hukum berbasis android dapat mempercepat masyarakat dalam mendapatkan pendampingan hukum 
2. Sistem konsultasi hukum berbasis android memberikan kemudahan bagi pejabat hukum dalam evaluasi dan monitoring perkara yang dihadapi oleh klien.

\subsection{Saran}

Beberapa saran yang dapat dilakukan untuk pengembangan lebih lanjut sistem yaitu:

1. Memiliki tampilan dashboard sistem bagi pejabat hukum, sehingga pejabat hukum dapat membuat laporan perkara-perkara yang telah ditangani.

2. Melakukan filter terhadap perkara atau permasalahan hukum yang diajukan dan ditangani oleh pejabat hukum.

\section{DAFTAR PUSTAKA}

[1] Kristanto, Andri. 2018, Perancangan Sistem Informasi dan Aplikasinya (Edisi Revisi), Gava Media, Yogyakarta.

[2] Fatta, Hanif Al. 20017, Analisis dan Perancangan Sistem Informasi, Andi Offset, Yogyakarta.

[3] Sutabri, Tata. 2016, Sistem Informasi Manajemen Edisi Revisi, Andi Offset, Yogyakarta.

[4] Reksoatmodjo, Wahyuni. 2018, Analisis dan Perancangan Sistem Basis Data, Andi Offset, Yogyakarta.

[5] Sutabri, Tata. 2012, Analisis Sistem Informasi, Andi Offset, Yogyakarta.

[6] Kadir, Abdul. 2014, Pengenalan Sistem Informasi Edisi Revisi, Andi Offset, Yogyakarta.

[7] Republik Indonesia, 2006, "Undang-Undang RI Nomor 18 Tahun 2003 Tentang Advokat”Dalam YLBHI dan PSHK, Panduan Bantuan Hukum di Indonesia, Jakarta.

[8] Supardi, Yuniar. 2011, Sетиa Bisa Menjadi Programmer Android, Elex Media Komputindo, Jakarta.

[9] Whitten, Jeffery L., Lonnie D. Bentley dan Kevin C. Dittman. 2010, Metode Desain dan Analisis Sistem, Edisi 6, Andi Offset, Yogyakarta.

[10] Nurjana. Wahyu, "Sistem Informasi Konsultasi Berbasis Web Studi Kasus: PT. Taspen (Persero) Cabang Bandung" JATI, Vol 02, 2013.

[11] Handoko, W.T., Lestariningsih, E., Ardhianto, E. 2014, Rancang Bangun Sistem Informasi Data Konsultasi Perkara Klien pada Biro Konsultasi dan Bantuan Hukum (BKBH) Universitas Stikubank (UNISBANK) Semarang. DINAMIKA INFORMATIKA Vol.6 No. 1, Maret 2014.

[12] Asnawi I., Mursityo Y.T., Pramono, D. 2018, "Pengembangan Sistem Informasi Lembaga Pengkajian dan Konsultan Bantuan Hukum (LPKBH) Menggunakan Zachman Framework (Studi pada LPKBH Al-Baihaqy)". Jurnal Pengembangan Teknologi Informasi dan Ilmu Komputer, Vol. 2, No. 9, September 2018, hlm. 2454-2461. 